P-ISSN: 2774-4574; E-ISSN: 2774-4582 TRILOGI, 2(1), Januari-April 2021 (1-5) @2021 Lembaga Penerbitan, Penelitian, dan Pengabdian kepada Masyarakat (LP3M) Universitas Nurul Jadid Paiton Probolinggo

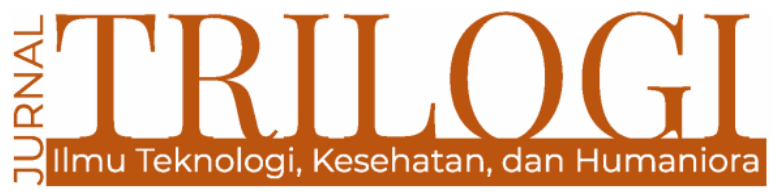
DOI: https://doi.org/

\title{
REDESIGH GRAVITATION WATER VORTEX POWER PLANT (GWVPP) STUDY KASUS DESA DUREN
}

\section{Muhammad Hasan Basri}

Universitas Nurul Jadid, Probolinggo, Jawa Timur

hasanmohammadbasri83@gmail.com

\section{Bayu Okta Pratama}

Universitas Nurul Jadid, Probolinggo, Jawa Timur

bayupatemon@gmail.com

\section{Muhammad Faisol}

Universitas Nurul Jadid, Probolinggo, Jawa Timur

muhammad.faisol49@gmail.com

\section{Ali Zainal Abidin}

Universitas Nurul Jadid, Probolinggo, Jawa Timur

Aal.Ajach.5@gmail.com

\section{Moh Arif Billah}

Universitas Nurul Jadid, Probolinggo, Jawa Timur

Muhammmadarifbillah@gmail.com

\begin{abstract}
Residents in remote areas have not been able to enjoy electricity, including Desa Duren, Gading District, located in the mountainous area south of Probolinggo Regency, where the village still does not receive electricity supply from PLN. Hydropower is a renewable energy that can be used as a substitute for generators, where this potential can be used to become a Gravitation Water Vortex Power Plant (GWVPP) already in the village, but it needs a touch of redesign. The results of the research on the reduction of gravitation water vortex power pland in Duren Village can be obtained that the electric power generated is 727.7 watts, where this power can supply electricity needs of 5 houses.
\end{abstract}

Keywords: Renewable energy; Gravitation Water Vortex Power Plant; Electrical power

\begin{abstract}
Abstrak
Penduduk didaerah terpencil belum dapat menikmati listrik, termasuk Desa Duren Kecamatan Gading terletak di daerah pegunungan sebelah selatan Kabupaten Probolinggo, dimana Desa tersebut masih belum mendapat pasokan listrik PLN. Tenaga air merupakan energi terbarukan yang bisa digunakan sebagai pengganti pembangkit, dimana potensi tersebut bisa di manfaatkan untuk menjadi Gravitation Water Vortex Power Plant (GWVPP) yang sudah ada di desa tersebut, akan tetapi butuh sentuhan redesain. Hasil dari penelitian redesaian gravitation water vortex power pland di Desa Duren dapat diperoleh daya listrik yang dihasilkan sebesar 727,7 watt, dimana daya tersebut dapat mensuplai kebutuhan listrik sebanyak 5 rumah.
\end{abstract}

Katakunci: Energi Terbarukan; Gravitation Water Vortex Power Plant; Daya Listrik. 


\section{Pendahuluan}

Penduduk Indonesia kebanyakan tinggal atau bermukim ditempat sulit untuk dijangkau, sehingga untuk menekan biaya yang digunakan perlu dibuat sebuah pembangkit listrik mikro agar penduduk didaerah terpencil sekalipun dapat menikmati listrik dengan biaya terjangkau (Komarudin dkk, 2020). Di Desa Duren Kecamatan Gading terletak di daerah pegunungan sebelah selatan Kabupaten Probolinggo, dimana Desa tersebut masih belum mendapat pasokan listrik PLN. Desa Duren sendiri mempunyai aliran air yang besar, dimana potensi tersebut bisa di manfaatkan untuk menjadi Gravitation Water Vortex Power Plant (GWVPP). Dari potensi aliran air tesebut masyarakat Desa Duren telah merancang Gravitation Water Vortex Power Plant (GWVPP) berbasis basin silinder (Nafi' dkk). Dimana vortex tersebut masih menggunakan cara tradisonal yang masih banyak menimbulkan bahaya dalam pemakaian aliran listrik.

Tenaga air merupakan energi terbarukan yang bisa digunakan sebagai pengganti pembangkit listrik berbahan bakar fosil. Tetapi aliran air tidak kesemuanya mempunyai head yang besar, sehingga belum bisa dimanfaatkan secara optimal (Tanjung et al, 2019). Menurut Irawan dwi, Energi air dapat dimanfaatkan sebagai pembangkit listrik dengan memanfaatkan tenaga potensial yang tersedia (potensi air terjun dan kecepatan aliran). Berdasarkan data Blueprint Pengelolaan Energi Nasional tahun (2005) (Suhartono, 2020). Berdasarkan uraian latar belakang diatas maka dalam penelitian ini akan meredesain pembangkit listrik tenaga vortex, supaya dapat layak dan aman dalam pemakaian.

Gravitational Water Vortex Power Plant adalah jenis green technology yang termasuk dalam kategori pembangkit listrik tenaga mikrohidro. Saat ini vortex dikategorikan sebagai pembangkit listrik mikrohidro karena daya maksimum yang dihasilkan tidak melebihi $100 \mathrm{~kW}$. Keuntungan utama dari pembangkit listrik ini adalah persyaratan head air yang sangat rendah serta ramah lingkungan. Di pembangkit ini, air melewati lubang masuk (Inlet) yang besar dan lurus, yang kemudian mengalir secara tangensial ke cekungan bundar. Air kemudian akan membentuk pusaran yang kuat, yang keluar dari saluran keluar (Outlet) di bagian tengah bawah dari basin seperti yang dapat dilihat pada gambar 1 (Wardhana, 2019).

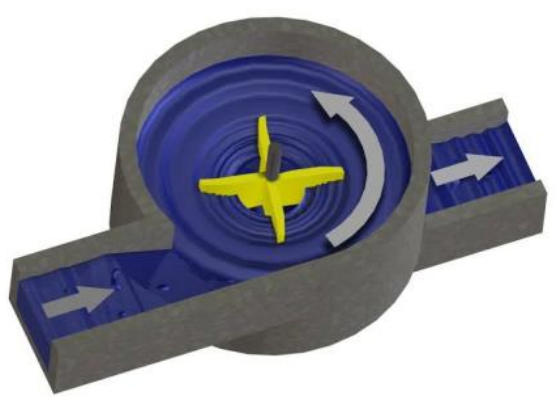

Gambar 1. Gravitational Water Vortex Power Plant

Sistem Turbin Vortex adalah sebuah teknologi baru yang memanfaatkan energi yang terkandung dalam pusaran air yang besar yang dibuat dengan menciptakan melalui Perbedaan head rendah di sungai (Tobing et al, 2019). Cara kerjanya:

1. Air Sungai dari tepi sungai disalurkan dan diarahkan ke tangki sirkulasi. Tangki sirkulasi ini memiliki suatu lubang lingkaran pada dasarnya.

2. Tekanan rendah pada lubang dasar tangki dan kecepatan air pada titik masuk tangki sirkulasi mempengaruhi kekuatan aliran vortex.

3. Energi potensial seluruhnya diubah menjadi energi kinetik rotasi di inti vortex yang selanjutnya diekstraksi melalui turbin sumbu vertikal.

4. Air kemudian kembali ke sungai melalui saluran keluar.

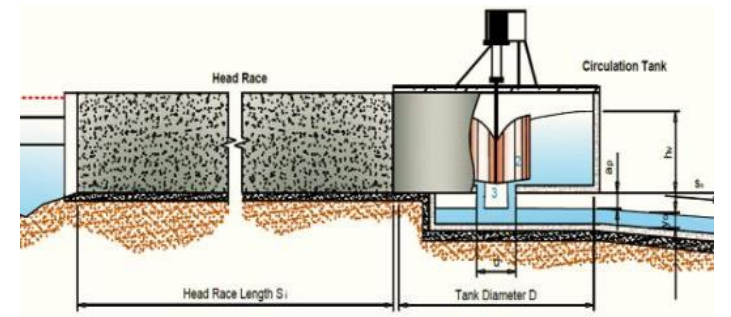

Gambar 2. Instalasi Turbin Vortex Pada Sungai

Generator sebagai pengubah energi mekanis menjadi energi listrik. Generator yang digunakan adalah generator 3 phase (Bahrullah dkk, 2020).

\section{Metode}

Metode dalam penelitian redesain gravitation water vortex power plant ini dilakukan dalam beberapa langkah, yaitu:

a. Persiapan alat dan bahan 
Dalam melakukan redesain vortex yang berada di Desa Duren memerlukan beberapa alat dan bahan yang harus dipersiapkan, diantaranya :

1) Tachometer digunakan untuk mengukur rpm

2) Tang meter digunakan untuk mengukur daya listrik yang dihasilkan

3) Avometer untuk mengukur arus dan tegangan yang dihasilkan.

4) Gerindra, bor, dan mesin las.

5) Besi sebagai penyangga turbin.

b. Desain redesain vortex

Untuk desain perancangan vortex yang akan di redesain, yaitu:

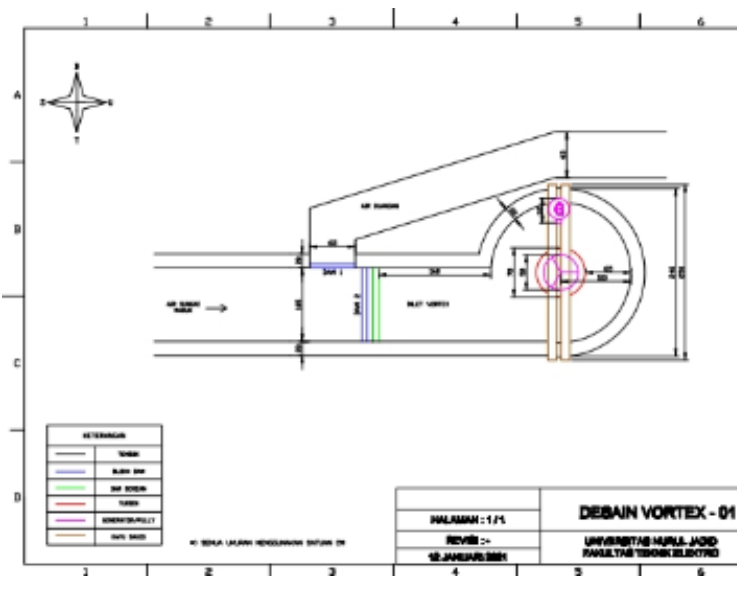

Gambar 3. Redesain Vortex

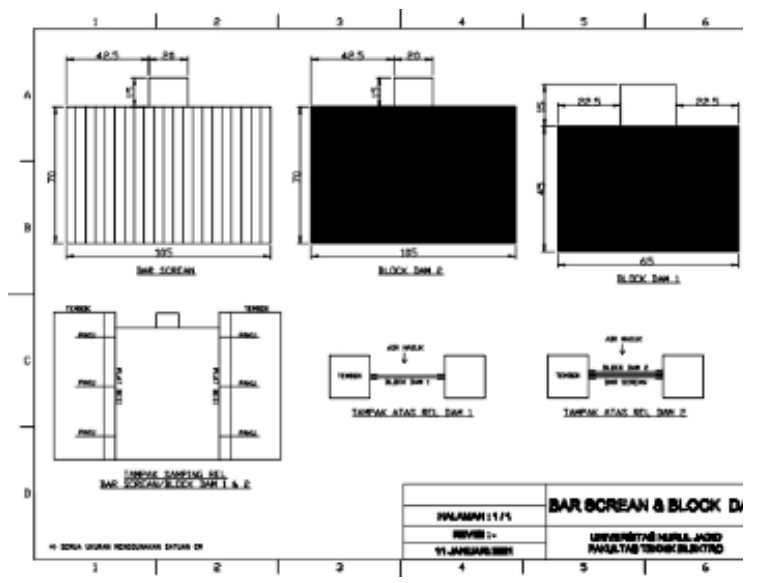

Gambar 4. Bendungan Aliran Vortex

\section{c. Pengujian Putaran yang dihasilkan}

Kecepatan sudut $(\theta)$ dapat dikonveriskan dari nilai Rpm yakni : $\omega=\frac{2 \pi r p m}{60}$. Berdasarkan hasil penurunan rumus di atas maka diperlukan nilai torsi terukur dari nilai rpm terukur (Haerudin dan Wahyu, 2016).
d. Pengujian Arus dan Tegangan yang dihasilkan

Pengujian untuk arus dan tegangan yang dihasilkan oleh vortex dengan menggunakan multimeter digital. Nilai yang terbaca pada multimeter adalah nilai tegangan dan arus yang dihasilkan oleh vortex di Desa Duren.

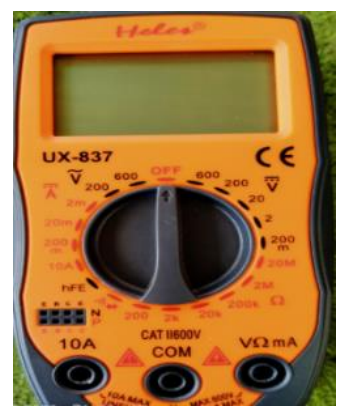

Gambar 5. Avometer

Cara kerja avometer adalah: 1. Mengatur terlebih dahulu switch selector pada posisi DCA (Direct Current Ampere) yang berfungsi untuk mengukur arus searah atau dapat dilihat pada gambar 3, (Nafi'dkk). Lakukan pengukuran dengan meletakkan kedua probe alat ukur pada rangkaina yang akan di ukur (alat ukur harus dipasang seri terhadap rangkaian), dan nilainya dapat langsung terlihat (Fredi, 2020).

e. Pengujian daya listrik yang dihasilkan

Daya Listrik atau dalam bahasa Inggris disebut dengan Electrical Power adalah jumlah energi yang diserap atau dihasilkandalam sebuah sirkuit/rangkaian. Sumber Energi seperti tegangan listrik akan menghasilkan daya listrik sedangkan beban yang terhubung dengannya akan menyerap daya listrik tersebut. Dengan kata lain, Daya listrik adalah tingkat konsumsi energi dalam sebuah sirkuit atau rangkaian listrik. Kita mengambil contoh Lampu Pijar dan Heater (Pemanas), Lampu pijar menyerap daya listrik diterimanya dan mengubahnya menjadi cahaya, sedangkan Heater mengubah serapan daya listrik tersebut menjadi panas. Semakin tinggi nilai Watt-nya semakin tinggi pula daya listrik yang dikonsumsinya. Daya listrik pada Rangkaian arus DC,daya listrik sesaat dihitung menggunakan Hukum Joule, sesuai nama fisikawan Britania James Joule, yang pertama kali menunjukkan bahwa energi listrik dapat berubah menjadi energi mekanik, dan sebaliknya (Muhlas, 2020). 


$$
\begin{aligned}
& P=V . I \\
& \text { Dimana : } \quad \mathrm{P}=\text { Daya Listrik (watt) } \\
& \mathrm{V}=\text { Tegangan (volt) } \\
& \mathrm{I}=\text { Arus Listrik (Amper) }
\end{aligned}
$$

\section{Hasil dan Pembahasan}

Dalam penelitian ini bertujuan untuk meredesaian pembangkit listrik tenaga vortex yang dimiliki oleh warga Desa Duren. Redesaian yang dilakukan adalah:

a. Tempat vortex agar dapat menghasilkan daya listrik yang maksimal untuk dapat di salurkan ke rumah-rumah.

b. Meredesain tempat generator agar menghasilkan arus, tegangan, dan daya yang maksimal.

Hal pertama yang dilakukan pada penelitian ini adalah meredesain tempat vortex, generator, dan saluran buang aliran air, agar dapat terhindar dari banjir, sampah, dan hujan. Untuk generator diberikan alat flowmeter untuk pembacaan tegangan.

Perhitungan daya listrik yang dihasilkan dilakukan dengan menggunakan rumus persamaan yaitu sebagai berikut:

$$
P=V . I
$$

Dimana : $\quad \mathrm{P}=$ Daya Listrik

$$
\begin{aligned}
& \mathrm{V}=\text { Tegangan } \\
& \mathrm{I}=\text { Arus }
\end{aligned}
$$

Hasil dari pengujian redesain keluaran vortex di Desa Duren meliputi rpm, arus, tegangan, dan daya listrik yang dihasilkan, dapat dilihat pada tabel 1 . Pengujian tersebut menggunakan alat ukur avometer, dimana hasil yag didapat yaitu:

Tabel 1. Hasil pengujian redesain vortex Desa Duren

\begin{tabular}{ccccc}
\hline No & $\begin{array}{c}\text { Rpm } \\
\text { (Put/ }\end{array}$ & $\begin{array}{c}\text { Arus } \\
\text { (A) }\end{array}$ & $\begin{array}{c}\text { Tegangan } \\
\text { (Volt) }\end{array}$ & $\begin{array}{c}\text { Daya } \\
\text { Listrik }\end{array}$ \\
\hline & mnt) & & & (Watt) \\
\hline 1 & 761 & 3,9 & 174 & 678,6 \\
\hline \hline 2 & 1219 & 3,9 & 185 & 721,5 \\
\hline 3 & 1362 & 3,5 & 190 & 665 \\
\hline \hline 4 & 1232 & 2,9 & 188 & 545,2 \\
\hline 5 & 800 & 4,1 & 177 & 725,7 \\
\hline \hline
\end{tabular}

Berdasarkan tabel 1, dapat dilihat bahwa hubungan antara arus dengan tegangan menghasilkan daya listrik secara teoritis. Dari tabel 1 diatas terlihat bahwa rpm tertinggi $1362 \mathrm{put} / \mathrm{mnt}$ dengan arus 3,5 A, tegangan 190 Volt yang menghasilkan daya listrik 665 watt, sedangkan rpm terendah $800 \mathrm{put} / \mathrm{mnt}$ dengan arus 4,1 A, tegangan 177 Volt, menghasilikan daya listrik 727, 7 watt.

Dari tabel 1 dapat diketahui bahwa rpm yang dihasilkan berpengaruh terhadap arus, tegangan dan daya listrik yang dihasilkan. Apabila rpm rendah maka daya listrik yang dihasilkan akan rendah, berbanding terbalik apabila rpm yang dihasilkan tinggi maka daya listrik yang dihaslikna akan tinggi. Maka dari hasil redesain gravitation water vortex power plant yang berada di desa duren daya listrik yang dihasilkan dapat dimanfaat untuk mensuplai daya listrik untuk 5 rumah, dengan daya listrik yang didapatkan pada pembagkit tersebut sebesar 725,7 watt.

\section{Penutup}

Hasil dari penelitian redesaian gravitation water vortex power pland di Desa Duren dapat diperoleh kesimpulan bahwa daya listrik yang dihasilkan sebesar 727,7 watt, dimana daya tersebut dapat mensuplai kebutuhan listrik sebanyak 5 rumah.

\section{Daftar Pustaka}

Moh. komaruddin, Muhammad Hasan Basri, Amalia Herlina. "Pengaruh Bentuk Blade Turbin L dan S pada Gravitation Water Vortex Power Plant (GWVPP) Berbasis Basin Silinder". CYCLOTRON P-ISSN2614-5499, E-ISSN2614-5164 VOLUME 3 NOMOR 2, JULI 2020

\footnotetext{
Mochammad Ilham Nafi', Muhammad Hasan Basri, Hilman Saraviyan Iskawanto, Bachtera Indarto, Alfi Tranggono Agus Salim."Rancang Bangun Gravitation Water Vortex Power Plant (GWVPP) Berbasis Basin Silinder".
}

I. F. Tanjung et al., "Analisa Performansi Turbin Vortex Menggunakan Perangkat Lunak Cfd Dengan Variasi Dimensi Sudu I Dan Sudu Iii, Debit Air 
Masuk Serta Luas Saluran Buang," J. Din., vol. 3, no. 4, 2019.

Suhartono, Ratih Indri Hapsari, Mohammad Zenurianto, Ikrar Hanggara. 2020. "Performa Model Tes Hidrolis Untuk PLTMH Head Rendah Menggunakan Tekanan Aliran Dan Kecepatan Pusaran Air (Vortex)". Reka Buana : Jurnal Ilmiah Teknik Sipil dan Teknik Kimia, 5 (1), 2020, page 28-36.

E. M. Wardhana, A. Santoso, and A. R. Ramdani, "Analysis of Gottingen 428 Airfoil Turbine Propeller Design with Computational Fluid Dynamics Method on Gravitational Water Vortex Power Plant," Int. J. Mar. Eng. Innov. Res., vol. 3, no. 3, 2019.

S. Tobing et al., "Analisa Rumah Vortex Berbentuk Lingkaran Dengan Variasi Diameter Lubang Buang Menggunakan Perangkat Lunak Cfd," J. Din., vol. 4, no. 4, 2019.

Muhammad Bahrullah, Muhammad Hasan Basri, Amelia Herlina, Bachtera Indarto. 2020. "Perancangan Generator 3 Phase Pada Gravitation Water Vortex Power Plant (GWVPP)". Jurnal Elemen, Vol.7 No.1 Juni 2020 ; pp. $46-53$.

Haerudin, \& Wahyu Dwi Prasetyo. (2016). Rancang Bangun Generator Sinkron 1 Fasa Magnet Permanen Kecepatan Rendah 750 RPM. Jurnal IImiah SETRUM, 5 (1).

Fredi Kusuma Putra, Muhammad Hasan Basri, Tijaniyah, Bahtera Indarto. 2020. "Pengaruh Ketinggian Turbin Model L dan Turbin Model S Pada Gravitation Water Vortex Power Plant (GWVPP) Berbasis Basin Silinder". Journal of Electrical and Electronic EngineeringUMSIDAISSN 2460-9250 (print), ISSN 2540-8658 (online) Vol. 4, No. 1, April 2020.

Muhlas Budi Utomo, Muhammad Hasan Basri, Fuad Hasan. "Eksperimen Variasi Tabung Basin Silinder Pada Gravitation Water Vortex Power Plant (GWVPP) Berbasis Basin Silinder".
CYCLOTRON P-ISSN2614-5499, EISSN2614-5164 VOLUME 3 NOMOR 2, JULI 2020. 